\title{
Mekân, Kimlik, Sinıf: Farklar Neden Bir Arada Barınamazlar?
}

*

\author{
Polat S. Alpman \\ Yalova Üniversitesi
}

\section{Öz}

Eşitsizlik ve ayrımcılık modern kapitalist toplumsal yapının bir parçasıdır. Eşitsizlik farklılaşmanın bir türüdür. Farkları eşitsizlik ve ayrımcılı nedenine dönüştüren koşullar, kapitalizmin tarihsel gelişiminin bir sonucudur. Mekân, bütün farklılaşmalarn somut hale gelip cisimleştiği; farkların eşitsizlik ve ayrımcılık haline dönüştüğ̈̈ ilk yerdir. Farklılaşmanın birçok nedeni vardır. Mekânsal farklılaşma, kaynakların eşitsiz dă̆̆lımıyla başlayan bir sürecin ürünüdür. Bu durum onu eşitsizlik olarak tanımlamanın ilk adımını oluşturur. Ancak mekânsal farklılaşmanın sürdürülmesine neden olan birçok eşitsizlik biçimi bulunmaktadır. Mekânsal farklılaşma sınıfsal, kültürel, etnik, dinsel, cinsel kimliklerin kente yerleşmelerinde, yer bulma davranışlarında ve yerleşim stratejilerinde belirleyicidir. Ayrıca mekânsal farkl-laşma toplumsal farklılaşmanın ve işgücü piyasasının yeniden düzenlenmesinin ön koşuludur. Mekânsal farklılaşma, kentteki yerleşimle ilgili bir farklılaşma olarak ortaya çıksa da farklılaşmanın nedeni toplumsal alanlardaki eşitsizliklerin örgütlenme biçimidir. Mekânsal farklılaşma ve kimlikler arasındaki ilişki dikey ve yatay hatta inşa edilir. Egemen kimliğin dışında kalan kimlikler üzerindeki tahakküm, mekânsal farklılaşma yoluyla yeniden üretilmektedir. Kimlik ve mekânsal farklılaşmanın iç içe girmesinin sonuçlarından biri işgücü piyasasının kimliklerle yeniden düzenlenmesidir. Ayrıca yeni elitlerin, kendilerine benzemeyen diğer sosyal gruplardan ve kimliklerden ayrışmaların să̆lamaktadır. Bu çalışma mekân, kimlik, sinıf kavramlarından hareketle farklılaşmanın mekânsal dinamiklerini ve farkların neden bir arada barınamadıklarını anlamayı ve açıklamayı amaçlamıştır.

Anahtar Kelimeler: Mekân, kimlik, sınıf, fark, kent. 


\title{
Space, Identity, Class: Why Cannot the Differences Coexist?
}

*

\author{
Polat S. Alpman \\ Yalova University
}

\begin{abstract}
Inequality and discrimination are part of the modern capitalist social structure. Inequality is a kind of differentiation. The conditions that transform differences into the cause of inequality and discrimination are the result of the historical development of capitalism. Space is where all differentiations become concrete and embodied and the first place where differences turn into inequality and discrimination. There are many reasons for differentiation. Spatial differentiation is the product of a process that begins with an unequal distribution of resources. This is the first step in defining it as inequality. However, there are many forms of inequality that cause spatial differentiation to continue. Spatial differentiation acts as a determinant in urban settlements, locating behaviors and settlement strategies of class, cultural, ethnic, religious and gender identities. It causes the reproduction of social differentiation and the reorganization of the labor market through spatial differentiation. Although spatial differentiation has emerged as the differentiation of settlement in the city, the reason for the differentiation is the way of organizing inequalities in the social fields. The relationship between spatial differentiation and identities is constructed on vertical and horizontal lines. The dominance over the identities positioned outside the dominant identity is reproduced through spatial differentiation. One of the consequences of the nesting of identity and spatial differentiation is the reorganization of the labor market with identities. It also leads to the separation of the new elites from other social groups and identities that bear no resemblance to them. This study aims to understand and explain the spatial dynamics of differentiation and the reasons why differences cannot coexist together.
\end{abstract}

Keywords: Space, identity, class, difference, city. 


\section{Giriş}

Bildiğimiz kentin sonuna geldik. Bildiğimiz, yani bir planlama ve çevre politikasının gözettiği faydalar ekseninde kurulan kentlerin sonuna geldik. XXI. yüzyıl kentleri yeni mücadelelerin mekânları olarak kurulurken içerisinde bütün toplumsal çelişkilerin gerçekleştiği eşitsizlik mekânları olarak var olacaklar. Kentlerin “...savaş meydanı olmaya devam edeceği kesin gibi görünmektedir. Örneğin, erişilebilir konut, yaşanabilir ücret ve çevresel adalet için sürdürülen yerel mücadeleler" (Theodore vd. 2012) neoliberalizmin yıkıcılığına karşı yeni mücadelelerin bir parçası olmakla birlikte onun ortadan kalkması için yeterli değildir.

Bunun nedenlerinden biri neoliberal üretim politikalarının ve ideolojisinin toplumsal alanlar ve ilişkiler içerisinde eşitsizlik ve ayrımcllı üretme enerjisinin henüz tükenmemesidir. Bunun çok yönlü eşitsizlikler ürettiği, ayrışma dinamiklerinin toplumsal alanların tümünde örgütlenen düzenlemelerle gerçekleştiği öne sürülebilir. Bunun kentteki görünümleri de sadece soylulaştırılmış ya da çöküntüleşmiş yerleşim yerleriyle değil, bundan çok daha yaygın ve geniş mekânsal farklılaşmaların kent ölçeğinde gerçekleştiği varsayımına dayanmaktadır. Planlı kentleşmenin ortadan kalktığı bir düzlemde -kelimenin tam anlamıyla- özel yerleşim yerlerinin sosyo-mekânsal ayrışmanın bir göstereni olarak ortaya çıkması; yüksek gelir gruplarının kendi yaşam stillerine, kimlik ve kültür değerlerine ve kendilerini kentin ötekileştirilen ya da marjinalleştirilen kesimlerinden farklı hissetmelerine neden olan yerler inşa ederek oralarda barınmalarındaki motivasyonlar sadece mekânsal farklılaşmanın bir sonucu değildir. Bu sosyo-ekonomik fraksiyonun mekânsal farklılaşma sayesinde kurduğu sınıfsal dayanışma ağları, eşitsizlik ve ayrımclık pratiklerini yeniden üretmeyi ve onu gerektiğinde inceltmeyi mümkün hale getiren habitusun mekânıdır. Kendi ekosisteminde inşa ettiği güvenlik, bu mekânın dışında kalanları olası tehdit nesnesine dönüştürmesi, onları kentsel korkunun yeni öznesi olarak işaret etmesi ve onlara şüpheyle bakmayı olağanlaştırması bu farklılaşmayı barınma ihtiyacı olarak sunmasını kolaylaştırır (Geniş, 2007; Wacquant 2014).

XXI. yüzyıldaki eşitsizlik ve ayrımcılıkların işgücünü, ücretli çalışan kesimleri hem dikey hem de yatay eksende bölen mekanizmalarla gerçekleşmesinin, kimliklerin ve göçmenlerin eşitsizliklerin ve ayrımcllkların nesnesine dönüşmesinin mekândaki karşılığı yerleşim ya da barınma farklılaşmasından çok daha geniş bir alanı kapsamaktadır. Bu kapsam enformelleşmeden milliyetçiliğe, tecritten güvencesizliğe kadar uzanan ve gündelik yaşa- 
mı kuşatan bir ilişkisellikle örülmektedir. Bu nedenle modern kapitalist üretim koşulları altında farklılaşmadan -spesifik olarak- mekânsal farklılaşmadan söz etmek, toplumsal eşitsizlik ve ayrımcılıktan söz etmek anlamına gelmektedir. Ayrışmanın ve farklılaşmanın mekânsal niteliğini üreten neden mekânın kendisi olamayacağına göre onu farklılaşmanın bir göstereni haline getiren ilişkilerin nasıl kurulduğu, nasıl örgütlendiği ve sürdürüldüğü eşitsizlik ve ayrımclık konusunun anlaşılmasında önemli bir yere sahiptir. Mekân sınıfsal eşitsizliklerin cisimleştiği yer olduğu kadar içerme dışlama mekanizmaları sayesinde tahakkümün de gerçekleştiği yerdir. Bu nedenle mekânsal farklılaşma, siyasal-iktisadi işleyişin eleştirisinin önemli bir parçası olarak kabul edilebilir.

Bu çalışmada yer alan üç bölümün ilki mekânsal farklılaşmayı toplumsal farklılaşmanın yansımalarından biri olarak ele alabilmek için mekân, kimlik ve sınıf kavramlarının eşitsizlik ve ayrımcılık ile içsel ilişkisini anlamayı hedeflemektedir. Metnin ikinci bölümü farklılaşma olgusunu eşitsizlik kavramıla ilişkisi üzerinden tartısmakta, üçüncü bölüm ise mekânsal farkl1laşmayı üç düzlemde ele alarak boyutlarını, yeniden üretilme dinamiklerini ve ekonomi-politik eleştirisinin işlevine odaklanmaktadır. Çalışmanın nihai hedefi, mekânsal farklılaşmanın nev-î şahsına münhasır bir niteliğe sahip olmadığını, sınıfsal dinamikler, egemen birikim rejimi ve stratejisiyle gerçekleşen bir oluş hali olduğunu ve bu farklılaşmanın toplumsal eşitsizlikayrımclık mekanizmalarıyla ilişkisini anlamak ve açıklamak olarak ifade edilebilir.

\section{Farklılaşmanın Kavramlarını Haritalamak}

Kavramlar boşlukta oluşmazlar. Sosyal bilimler içerisinde kullanılan kavramlar hem sürekliliğe sahiptir hem de bir bağlam çevresinde örülür. Kavramlar süreklilik ve bağlam içerisinde gelişir, açımlanır ve idrak edilir. Eşitsizlik ve ayrımcılık çalışmalarında kavramların içeriğine ve niteliğine ilişkin tartışmalar özel bir yer tutar. Bunun başlıca nedeni kullanılan kavramların belli bir soyutlama işlemini gerektirmesi ve kullanım çeşitliliğine ilişkin sınırlamalar içermesidir. Her tanımlama girişimi gerçekliğin bir boyutunu dışarda bıraktığı için bu sınırlamalar işe yaradıkları sürece eleştirinin de konusu olmaya devam ederler.

Kavramlara ilişkin bu epistemolojik önerme, farklılıkları açıklamak için kullanılan kavramlarla eşitsizlik ve ayrımclığı açıklamak için kullanılan kavramların örtüşmek ya da kesişmek zorunda olmadıklarını ima edebilir. 
Örtüşmeleri ve kesişmeleri mümkün hale getiren şey kavramların olgusal içerikleri, bunların sosyal gerçeklik içinden seçilip inşa edilme prosedürleridir. Fizik alanında evrensel çekim yasasından söz edilemeyeceği gibi bütün farklılıkların nedeni olan evrensel bir yasadan da söz edilemez. Ancak farklılıkları eşitsizlik ve ayrımcılık ilişkilerinin bir parçasına dönüştüren yapılaşmalardan, süreçlerden, ilişkilerden söz etmek mümkündür. Bunun nedeni ise egemen toplumsal formasyonun küresel niteliğidir. Bu nedenle mekân, kimlik, sınıf ve farklılaşma ilişkisini ve bunların diyalektik bağını anlamak ve açıklamak için kavramların bağlamını yeniden kurmak gerekir.

\section{Mekân}

Mekân kavramının içeriği ve kapsamı geniş bir soyutlama imkanı sunduğu için kavramı sınırlamak kolay değil. Terim olarak mekânın tanımlanmaya ihtiyacı yok. Ancak kavram olarak sadece tanımlanmaya değil, kavramın ne işe yaradığının da gösterilmesi gerek. Lefebvre'den başlayıp günümüze kadar uzanan dar literatür içerisinde mekân kavramına ilişkin birçok farklı tanımın yapıldığı bilinmektedir. Bu çalışmada kullanılan mekân kavramı, bir yönüyle sosyoloji literatürünün perspektifini içerir ve buna göre mekân kavramı, sabit, değişmez, tarihsiz -özetle metafizik- ve formel değil, sosyal ilişkilerin, üretim ilişkilerinin ve ideolojinin yeniden üretildiği yer olarak tanımlanabilir.

Sabitlenemeyen mekân kavrayışı sosyalliğin, üretimin ve ideolojinin inşa edildiği ya da kurulup söküldüğü ve yeniden kurulduğu yeri işaret etmektedir. Bu nedenle binlerce yıl aynı formu koruyan (ve farklı işlevleri yerine getiren) anıtlar kadar havaalanları arasında mekik dokuyan uçaklar, hatta bazı internet teknolojisinin imkanlarıyla ortaya çıkmış olan ve adına 'sosyal medya' denilen ${ }^{1}$ ortamlar da mekân kavramının içerisinde yer alır.

\footnotetext{
${ }^{1} \mathrm{Bu}$ galat-1 meşhurun, yaygın yanlış kullanımın işaret ettiği gerçeklik, Gerçek Zamanlı Elektronik İletişimin (GZEI) sunduğu olanakların bu ilişkiye katılanlar için -hatta kimi zaman katılmayanlar için de- işlevinin ne olduğu sorusuyla ilgilidir. Mevcut haliyle “...bireylerin gündelik hayatlarını belirlemek için kullanabilecekleri küresel boyutta ve çok sayıda enformasyon akışı" günümüzdeki egemen iletişim kültürünü oluşturmaktadır. "Bunu 'toplumsal düşünümsellik' olarak" kavramsallaştırdığımızda, bu teknolojilerin üretimden sosyal ilişkilere, ideolojiden yerleşim düzenlemelerine kadar birçok alanda verilen kararları belirleyen bir etkiye sahip olduğu öne sürülebilir. Bu nedenle "siyasal olanın ne olduğu, siyasal kurumların işlevleri üzerine geliştirilen yeni fikirler, şehirleşme ve bireyselleşme, yerelleşme, GZEİ araçlarının etkisiyle bireysel olanın ... daha da politik olduğu düşüncesi gibi düşünceler ve pratikler artık devlet ve partiler gibi örgütlü yapılar başta olma üzere geleneksel siyasal sistemlerin anlamını ve hatta varlığını tartışılır hale" getirmekle birlikte kendilerini yeni mekânlar olarak inşa etmektedirler (Yarcı, 2017). Başka
} 
Yukarıda yapılan ve mekânı sosyal ilişkilerin, üretim ilişkilerinin ve ideolojinin yeniden üretildiği yer olarak ele alan tanım, mekânın bir mücadele yeri olduğunu, değişim ve dönüşüm için zorunlu olan dinamiklerin burada ve burası aracilığıyla oluşturulduğunu öne sürmektedir. Mekân kavramına ilişkin bu çerçeve kentin nasıl organize edildiği sorusuna yönelik bir perspektif de içermektedir. Yine bu tanımlanmanın gösterdiği bir diğer husus, mekânın egemen birikim stratejisiyle olan ilişkisidir. Özetle toplumsal alanlarda var olan her şeyin mekânda bir karşılığının bulunduğu ve mekânın, ilişiksiz görünen şeylerin ilişkilendiği yer olarak değerlendirilmesi gerektiği öne sürülebilir.

\section{Kimlik}

Çalışmanın problematiğini oluşturan ve farklılaşma olgusunu açıklamak için kullanılan bir diğer kavram olan kimlik, bireysel deneyimlerin kolektif inşası olarak kavramsallaştırılmaktadır. Bu kavramsallaştırmayı tartışmadan önce sosyoloji içerisindeki bazı yaklaşımların kimlik konusuyla ilgili temas ettikleri bazı hususlardan bahsetmek gerekir. Çünkü kimlik kavramının sosyal bilimler içerisindeki analitik işlevi halen tartışma konusudur. Kavramın içerdiği farklı, çoklu ve kesişimselliğe olanak sağlayan anlamların yoğunluğu, kavramın açılayıcılık potansiyelini arttırmakta (Sökefeld, 2001), istismarını ve bağlamsız kullanımını kolaylaştırmaktadır.

Bazı sosyal bilimciler kimlik kavramını sosyal bilimler için neredeyse sabit/mutlak bir kavram olarak değerlendirirken kavrama kendi başına bir özgüllük ve açıklama gücü atfederler. Onlara göre sosyal değişimlerin ve dönüşümlerin hızına ve yoğunluğuna rağmen kimlikler bir referans noktası olarak sabit durmaktadır. Bu nedenle sosyal bilimlerin kimliği göz ardı ederek sosyalliğe ilişkin analiz ve eleştiri yapması mümkün değildir (Hall, 1997; 2003). Bazı sosyal bilimciler ise kimlik kavramının birçok anlamda ve bağlamda kullanıldığını, bu nedenle açılayıcılık gücünün bulunmadığını öne sürmektedir. Sosyal bilimler literatürü içinde kimlik kavramı, analiz içerisinde farklı yerler işgal ettiği için farklı biçimlerde tanımlanmaktadır. Kimlik kavramıyla karşılanan bu farklılıkların, başka kavramlar geliştirilerek ele alınması gerektiğini ifade eden bu yaklaşım, toplumsal alanların analizinin "kimliğin ötesine" geçmesi gerektiğini öne sürmektedir (Brubaker ve Frederick, 2000).

bir çalışmada "dijital mekânlar" olarak ifade edilen bu yaklaşım, sosyalliğin mekânı olarak GZEI'nin sunduğu imkanlara gönderme yapmaktan daha çok, bu mekânın ürettiği yeni ilişki ağlarına ve örüntülerine odaklanmaktadır (Göker, 2017). 
Klasik sosyoloji içerisinde kimlik, Durkheim'in "kolektif bilinç", Marks' in "sinuf bilinci", Weber'in "idrak" (Verstehen), Tönnies'in "cemaat" (Gemeinschaft) şeklinde ifade ettiği kolektif kategoriler içerisinde tanımlanmaktadır (Cerulo, 1997). Bu yaklaşımlar kolektif kimliği bir kök ya da kökenle ilişkilendiren ve "biz" kurgusunu ortaya çıaran dinamiklere odaklanmaktadır. Bu yaklaşımlara göre gündelik yaşamın ve maddi pratiklerin içerisinde gerçekleşen bireysel davranışların soyutlanmasıyla elde edilen ilişkilerin (Jenkins, 2004) kimlik olarak deneyimlenmesi, sembolik, simgesel ve zihinsel inşalar sayesinde görünür hale gelmektedir.

Sosyal bilimler içerisinde kimliği bir etkileşim biçimi olarak ele alan sembolik etkileşim yaklaşımı ise benlik kavramından hareket ederek, psikolojinin konusu olan bireyi sosyolojinin konusu haline getirir. Birey, sosyal gruplar içinde yer alan bir özne olmaktan çok, kendisi ve kendisi dişında yer alan grup üyeleriyle ilişkisi yoluyla tanınır, tanımlanır ve böylece bireyin kendisiyle ve çevresiyle kurduğu ilişki açıklanabilir hale gelir. Mead bireyin ilişki içerisinde olduğu diğerlerini tanıyarak kendi farkındalığına erişebileceğini, kendini tanımlayabileceğini öne sürer. Bu nedenle öteki kavramının kökleri burada, bu aşamada aranabilir. Çünkü öteki, bireyin bir benlik olarak kendisini fark etmesiyle birlikte ortaya çıkmaktadır (Santas, 2002; Taylor ve Spencer, 2004). Mead, Blumer, Goffman ile temsil edilen bu yaklaşım, kimliği bireyin kendini ve çevresini -dolayısıyla dış çevreyi- tanımlama bilinci olarak açıklayarak kişilerarasındaki uyum ve çatışmayı bu analiz çerçevesine yerleştirirler.

Kimliği sosyal inşa olarak değerlendiren yaklaşım ise sosyal gerçekliğin şimdi ve burada gerçekleşen bir düzenleme olduğunu öne sürer. Yaklaşıma göre gündelik gerçeklik, mekânsal ve zamansal olarak farklı düzeylerde deneyimlenen gerçekliğin analiz edilmesiyle elde edilebilir (Berger ve Luckmann, 1991). Sosyal gerçekliğin öznel olarak inşa edilmesinde kimlik başlıca belirleyicidir. "Kimlik sosyal süreçler tarafından biçimlendirilir" ve bir kez ortaya çıtıktan sonra "sosyal ilişkiler tarafından süreklileştirilir, değiştirilir ve yeniden şekillendirilir." Kimliğin bu diyalektik karakteri, bireyler arasında niteliksel ayrımlar yapılmasına olanak veren kimlik tiplerine neden olur. Kimlik tipleri sayesinde bireyler içerisinde bulundukları koşullara uyumlu ya da onlarla çatışan tutum ve davranışlar sergiler; bu süreç, gerçekliğin sosyal olarak yeniden inşa edilmesini sağlar.

Bu yaklaşımlar bireyi bir çevre içerisinde üretilen kolektif kimlik ürününün taşıyıcısı olarak konumlandırmaktadır. Kimliğin kolektif bir niteliği olmakla birlikte, onun bir deneyim olarak tanımlanması, bireyin kişisel deneyimlerinin bir sonucu olduğu anlamına gelmez. Kuşkusuz kimliğin 
oluşmasında bireyin deneyimi önemlidir, ancak kimlik, bireysel deneyimlerin soyutlanmasıyla elde edilen kolektif bir inşa olarak değerlendirilmelidir. Bu nedenle 'kimlik bir deneyimdir' önermesi, kişinin bireyselliğini aşan ve onu içinde yer aldığı sosyal çevrenin deneyimlerine bağlayan sürecin içerisinde anlam kazanmaktadır. Öyleyse, farklılaşmayı açıklamak için kimlik ya da kültür gibi soyut, açıklama gücü tartışmalı ve tarifi zor kavramlardan daha çok gündelik yaşam içerisinde yer alan, maddi yapılaşmaların içerisinde oluşan ve ortaya çıkan sınıf, iktidar, aile, göç ve mekân gibi olguların bileşkesinde inşa edilen kimliklerin niteliklerini ve işlevlerini anlamak gereklidir.

\section{Sinıf}

Farklılaşmanın bir eşitsizlik ve ayrımcılık rejimi haline gelmesini açıklamak için kullanılan başlıca kavramlardan biri sınıftır. Üretim ilişkilerinin, başta ekonomi olmak üzere toplumsal alanların küreselleşmeyle ilişkisinin, işgücünün yeniden örgütlenmesinin mekân-zaman sıkışması sonucu hızlı ve etkili bir dönüşüm geçirdiği; iktidar ve tahakküm mekanizmalarının toplumla ilişkisinin devletlerle sınırlandırılamayacak bir aşamaya geldiği birçok sosyal bilimci tarafından ifade edilmektedir (Carnoy ve Castells, 2001). Bütün bu tartışmalar içerisinde nesnel ya da sosyal sınıf konseptine ilişkin yeni bir bakış açısının gerekli olduğu, geçmişteki sınıfsal kategorilerin ileri kapitalist toplumları açıklamakta yetersiz kaldığı, burjuvazi ve proletarya kavramlarının açıklama olanaklarının daraldığıyla ilgili birçok açıklama geliştirildi (Laclau ve Mouffe, 2008; Wood, 2006).

Ancak XXI. yüzyıla girildiğinde sosyal bilimler içerisinde sınıf konseptinin yeniden gündeme geldiği, neoliberal ekonomi-politik, enformelleşme, güvencesizleşme ve toplumsal alanların tümünde egemen hale gelen prekarizasyon olgusuyla birlikte sınıf tartışmalarının yeniden yükseldiği görülmektedir. Bu yükselişin nedenlerinden biri ekonomi alanında yaşanan çoklu gerilimler olmakla birlikte, otoriterleşme tartışmalarında görüldüğü üzere, çözülmekte olan siyasal-kültürel modeller, göçmenler üzerinden dile getiren yeni sosyal-ekonomik nedenler, siyasal-iktisadi rejimin içsel çelişkilerinin neden olduğu gerilimlerin küresel yansımaları bulunmaktadır. Bu nedenle sınıf, küreselleşmenin neden olduğu sorunları da içerecek şekilde yeniden gündeme gelmektedir (Standing, 1999; 2011).

Ücretli çalışanların proleter, yani “iktisadi anlamda, 'sermaye'yi üreten ve değerlendiren ve ... [sermayenin] değerlenme ihtiyaçları bakımından gereksiz hale gelir gelmez sokağa atılan ücretli isçi" (Marx, 2011) ya da -precarious (güvencesiz, istikrarsız, tehlikeli) ve proletariat (proletarya) kavramlarının 
birleştirilmesiyle elde edilen- prekarya olarak tanımlanmasl, niteliksel olarak farklı olsa da sınıfsal konumları göstermesi bakımından, belirleyici değildir. Bunun nedeni esnek emek piyasasının halihazırda kurulmuş olması ve işçi sınıfının, küresel ölçekte parçalanmasının tamamlanmış olmasıdır. Günümüzde ücretlilerin hemen hepsi benzer koşullar altında çalışmakta ve güvencesizlik bütün yakaları ve iş kollarını birleştirebilecek düzeye erişmeyi başarmıştır. Ancak sınıfsal konum ve aidiyet bakımından benzer koşulların ortaya çıkması kişiler ya da topluluklar arasında eşitsizlik ve ayrımcılık motivasyonuna neden olan farklılıkların ortadan kalkmasını sağlamadı.

Sınıfı bir 'yapı' ya da 'kategori' olmaktan çok kişinin sahip olduğu sosyal rolü ve işlevi "nasıl edindiği ve belirli bir toplumsal örgütlenmenin (mülkiyet hakları ve otorite yapısıyla) nasıl oluştuğu" sorusuna (Thompson, 2004) verilen cevaplarda arayan yaklaşımlar, sınıfı gündelik yaşamın içerisinde inşa edilen sosyo-politik süreçlerde ve ilişkiler kümesinde aramaktadır. Sınıflar toplumsal eşitsizliklerin ve ayrımcilıkların temeli ve nedeni olmakla birlikte; bu eşitsizlikler ve ayrımclıklar üzerine inşa edilen sınıfsal farklılıklar, sosyal süreçler içerisinde yeniden üretilen ilişkinin kendisidir. Nesnel ya da maddi yapılar içerisinde yer alan failin bütün pratikleri, içinde yer aldığı ve bu alanlarda gerçekleşen fiillerle sınırlı değildir. Aynı zamanda failin, faillere ve yapılara müdahalesi ve onlarla ilişkisi ile birlikte oluşan diyalektik bir süreçtir (Thompson, 2006) ve bu nedenle sınıf bir ilişkidir.

Sınıfı bir ilişki olarak tanımlamak, bu ilişkinin kapsamının ve sınırlarının belirlenmesiyle bağlam kazanır. Sınıfın, sınıfsal ilişkilerin tarihsel ve kendini yeniden üretme dinamiklerine bağlı olduğu düşünüldüğünde, Hirsch'in klasik sorusunu sınıf üzerinden sorarak tartısmaya devam edilebilir: Sınıfın "hem mekân, hem de zaman bağlamında özel bir tarihsel biçim almasına yol açan değişimler neden meydana geliyor?" (Hirsch, 2011). Bu soru cevaplanması kolay bir soru değil, ancak sınıfı sabit ve mutlak olarak kavramak yerine onu sürekli aksiyon halinde, kendisi dışındaki dinamiklerin etkilerine açık ve siyasal, sosyal, ekonomik ve benzeri alanlarla mücadele içerisinde hareket eden, yapısallaşma eğilimindeki nitelikleri üzerinden değerlendirmeyi sağlar. Bu yaklaşım sınıfın kendini nerede ve nasıl gösterdiğini, mekân ve kimlik üzerinde nasıl bir etkiye ve işleve sahip olduğunu anlamak için başlangıç noktası olarak kabul edilebilir. 


\section{Eşitsizlik ve Farkların Fitratı}

Eşitsizlik konusunu sosyolojinin araçlarıyla anlamak ve açıklamak için öncelikle sosyolojinin bir bilimsel alan olarak özerk olması gerekir. Sosyoloji farklılıkları ve bunlar arasındaki ilişkileri, bu ilişkilerin oluşmasına ve değişmesine neden olan koşulları anlamak ve açıklamak gibi bir girişim içerisinde olsa da (Blau, 1977), bunu iktidar ilişkilerinden bağımsız gerçekleştiremez.

Sosyal bilimciler için eşitsizlik konusu sadece akademik değil, aynı zamanda siyasal ve ahlaki bir ilgi alanı olarak değerlendirilebilir. Eşitsizliğin siyasal boyutu ekonomi-politik nedenlerden kaynaklanan ve eşitsizliklerin temelini oluşturan sistemli yapıların ya da yapılaşma eğilimindeki hareketin ve işleyişin bir sonucu olarak kabul edilebilir. Ahlaki boyutu ise eşitsizliğin ve ayrımcllı̆ın neden olduğu acıların, kederlerin ve sorunların ortadan kalkmasıyla ilgili tarihsel mücadeleyle ilgilidir. Eşitsizlik sorunu, diğer birçok sosyal olgudan farklı olarak, toplumsal alanların tümünü dikey ve yatay olarak kesmektedir. Bununla birlikte eşitsizliklerin içselleştirilmesini sağlayacak mekanizmaları üreten egemen ideoloji de eşitsizlik ve ayrımcılık konusu içerisinde değerlendirilmektedir.

Eşitsizlik modern kapitalist toplumların gündelik yaşam tecrübelerine içkin deneyim setlerinin bir parçasıdır. Bu nedenle eşitsizlikten söz etmek, toplumsal alanların içinde gerçekleşen ilişki örüntülerinden söz etmek anlamına gelir. Buna rağmen eşitsizlik konusu hem siyasetçiler hem de sosyal bilimciler tarafından sıklıkla ekonomi alanına ilişkin bir problem olarak tanımlanmaktadır. Bauman (2011) eşitsizliğin ekonomi alanına indirgeyerek açıklanmanın, onu bir asayiş ve düzen sorunu olarak ifade etmenin bir başka biçimine ve "bireylerin fiziksel ve ruhsal sağlığını, günlük yaşam kalitesini, siyasal yaşama katılımın gidişatını ve toplumu birleştiren bağların gücünü ne boyutta tehdit ettiğini görmezden" gelmeye neden olduğunu söyler. Bu nedenle eşitsizlik "siyasi sınıf" tarafından, toplum olma halini etkileyen ya da engelleyen bir tehdit olarak değil, altsınıfların geçimlerine ilişkin bir mesele olarak değerlendirilmektedir.

Gelir eşitsizliğinin egemen üretim biçimi rejiminden kaynaklanan bir norm olması, kapitalist üretim biçimi içinde bunu çözmeye yönelik girişimlerin sonuç vermemesi ve özel mülkiyet rejiminin ayn zamanda bir imtiyaz rejimi olması, eşitsizlik konusunu ekonomik alanın başıca konusu haline getirir. Ekonomik eşitsizlikler, sosyal sınıflarla ilgili bir eşitsizlik biçimidir. Sınıf, toplumun üyesi olan kişileri toplumsal alanlarla bağlayan bir ilişki 
biçimi olduğu için, ekonomik eşitsizlikler diğer toplumsal alanlarda deneyimlenen bir ilişki biçimine dönüşmektedir. Bu nedenle liberal ekonomi diliyle ifade edilen gelir düzeyindeki eşitsizlikler, etnik, cinsel, dinselmezhebi, ırksal, bedensel ve yaş farkından kaynaklanan eşitsizliklere neden olmaktadır.

Eşitsizlik farklılaşmanın bir türüdür. Toplumsal eşitsizlik, sınıfsal konumlara, statü mevkilerine, tahakküm gücünün sınırlarına, toplumsal grupların çıkarlarını dayatabilme olanaklarına göre farklılıklar içerebileceği gibi her farklılık eşitsizliklere neden olmak zorunda değildir. Buna rağmen egemen toplumsal formasyonun düzenlenme biçimi, farklılıkları eşitsizliğin bir formu haline getirdiği için eşitsizlik sosyolojinin ilgi konularından biri olagelmiştir. Turner (1997), sıklıkla referans gösterilen, Eşitlik isimli eserinde yapısal-işlevselci metodolojinin eşitlik konusuyla ilgili yaklaşımlarını değerlendirirken günümüzde yoğunlaşan eşitsizliği, toplumun işlevinin değişimine bağlamaktadır. Eşitsizliği toplumsallığın doğasıyla ilişkilendirme iması taşıyan bu analitik çerçeve, nihai olarak eşitsizliği toplumsal farklılaşmanın bir türü olarak tasvir etmektedir. Toplumsal farklılaşmanın eşitsizlik formuna dönüşmesinin nedenini işlevlerdeki farklılaşmayla açılamak, farklılaşmanın kendisine bir öz atfetmek anlamına gelir. Oysa farklar kendilerini var eden ilişkiler içerisinde inşa edilirler, kendinde şeyler olarak var olmazlar. Farkların eşitsizlik olarak ortaya çıkması, bu farkları bir eşitsizlikayrımcılık nedeni olarak işlevsel hale getiren koşulların neler olduğunun açıklanmasıyla anlaşılabilir.

Farklılıkların kendi içlerinde taşıdıkları bir öz, cevher ya da sabit, mutlak, tarihsiz nitelikler nedeniyle var oldukları yönündeki bütün yaklaşımların idealist perspektife bağlı zihinsel inşalar olduğu, gerçekliğin olduğu halde ortaya çıkmasına neden olan kendi iç dinamiklerini, motivasyonlarını ve bunları ortaya çıaran ilişkiselliği ters yüz eden bir analiz çerçevesi sunduğu öne sürülebilir. Fark 'kendinde şey' değildir. İçinde yer aldığı koşulların ve ilişkilerin bileşkesinde inşa edilen, sökülen ve yeniden inşa edilen bir süreçtir. Bunu, fenomen haline gelen sosyal gerçekliğin tekrarları içerisinde izlemek mümkündür. Bu fenomenlerden hiçbiri bu işleyişi, süreci ve bütünlüğü yekpare olarak izlemeye olanak vermez. Yine de bu sosyal gerçekliğin hareketini ve işleyişini bir bütün halinde izlemeye en fazla yaklaşılan yer mekândır. Çünkü mekân, bütün farklılaşmaların somut hale gelip cisimleştiği; farkların eşitsizlik ve ayrımcılık haline dönüştügü ilk yerdir. 


\section{Farkları Mekânlaştırmak, Mekânda Farklılaşmak}

Kentler üretim, tüketim, dağttım, bölüşüm ve mübadele süreçlerinin ve ilişkilerinin gerçekleştiği mekânlardır. Bu süreçlerin ve ilişkilerin düzenlenmesi geri kalan toplumsal alanların düzenlenmesine neden olur. Ekonomik sermayenin birikimini devam ettirebilmesi için küresel, bölgesel ve yerel düzlemde hareket edebilmesinin sürekliliğini sağlamak gerekir. Bu düzenlemeler ekonomiyi olduğu kadar aileden hukuka, eğitimden siyasete toplumun geri kalan bütün alanlarını kapsamaktadır. Ayrıca üretim ilişkilerinin (Lipietz, 1988), üretim rejiminin (Nielsen, 1991), devletin (Jessop ve Sum, 2006; Pierson, 2004) ve gündelik yaşamın bir arada düzenlenmesini içerir. İşgücünün sadece üretim karşısında değil, aynı zamanda gündelik yaşamın içerisinde, sermaye birikiminin ve hareketinin güncel stratejilerine uyumlu hale gelebilmesi (Burawoy, 1983) için toplumsal alanların düzenlenmesi gereklidir.

Farklılaşmanın nedenlerinden biri kaynakların eşitsiz dağılımıdır. Bu önerme mekânsal farklılaşmayı bir eşitsizlik olarak tanımlanın ilk adımını oluşturur ve mekânsal farklılaşmayı bir adalet sorunu olarak gündeme getirmeyi sağlar. Mekânsal farklılaşmanın bir adalet sorunu olarak gündeme getirilmesi yerleşim-barınma-ikamet ayrımcılığına vurgu yapmayı amaçlar. Bu tür bir ayrımcılık, toplumdaki sosyal adaletin var olmadığını gösteren somut örneklerden biridir. Mekânsal farklılaşmanın yoğunluğu toplumdaki sosyal adaletsizliğin gösterenlerinden biridir (Marcuse, 2009; Soja, 2009). Bu nedenle mekânsal farklılaşma toplumda var olan çelişkilerin ve gerilimlerin somutlaştığı ve itaat kadar itirazın, rıza kadar isyanın da örgütlendiği ve gerçekleştiği yerdir.

Soja (2009), mekân üzerine eleştirel düşünmenin üç ilkeye dayandığını ifade eder. Bunlardan ilki ontolojik olarak mekânsal varlıklar olduğumuzu hatırlamak, ikincisi mekânın sosyal olarak üretildiği ve bu nedenle sosyal imkanlarla değişebileceği, üçüncüsü ise sosyo-mekânsal diyalektiktir; mekân sosyal olanı şekillendirirken sosyallik mekânsal olanı şekillendirmektedir. Mekânsal farklılaşmayı tümel bir fenomen olarak sosyalliğin kendisine bağlamak, sosyalliği kuran çoklu ilişkilerin dışında düşünmemek kaydıyla anlamlı kabul edilebilir. Bu nedenle mekânın 'sosyal ürün' olması, farklılığın kaynağını ve nedenini anlamak için aranan yollardan biri olmaktan daha çok farklılıkların kendini gösterme ve içselleştirilme ya da gizlenme ve direnme biçimlerine ilişkin çoğul ve dinamik taktik setleri içermesi olarak kabul edilebilir. Farklılaşmanın sosyallikle açıklanması, farkların 
mekânlaşması ve mekânların farklılaşması arasındaki diyalektik ilişkiyi sosyalliğe, sosyal ilişkilerin belirsizliklerle malul akışına bağlama eğilimindedir. Oysa mekânsal farklılaşma, soyut haldeki sosyalliğin değil, gündelik yaşamın ve toplumsal alanların içerisinde yer alan bütün ilişkilere mündemiç toplumsal farklılaşmanın tezahürlerinden biri olarak ortaya çıkar ve yeniden üretilir.

\section{Farklılaşmanın Boyutları}

Mekânsal farklılaşmanın gerçekleşmesine neden olan birçok eşitsizlik biçimi bulunmaktadır. Ekonomik alandaki eşitsizliklerin mekâna yansıma biçimlerinden biri işgücü piyasasına ve enformelleşmeye ilişkin düzenlemelerdir. Ekonomik alanın ve üretim ilişkilerinin yeniden düzenlenmesi, kentlerin düzenlenme biçimlerinin ve mekândaki örgütlenme örüntülerinin yeniden düzenlenmesini içerir. Bu düzenlemeler sinıfsal, kültürel, etnik, dinsel, cinsel kimliklerin kente yerleşmelerinde, yer bulma davranışlarında ve yerleşim stratejilerinde belirleyici hale gelir. Kentteki farklılaşmanın yeniden üretilmesine ve mekânsal farklılaşma yoluyla işgücü piyasasının yeniden düzenlenmesine neden olur.

Yerleşim sürecindeki ayrımcılık, mekânın ekonomik düzenlemelerin yörüngesinde örgütlenmesi ve mekânsal farklılaşma nedeniyle kentte ortaya çıkan faydanın/zararın eşitsiz dağılımı mekânsal farklılaşmanın bir sonucudur. Mekânsal farklılaşma, kaynakların eşitsiz dağılımı, ekonomik olduğu kadar sosyal, kültürel ve siyasal koşullarla ilişkilidir. Mekânsal farklılaşma, benzerlikleri ve farklılıkları belirler, ayrıştırır ve bütünleştirir. Böylece ayrıştırılanlar kendi içlerinde bütünleştirilir. Bunun yeni gettolaşmalara neden olduğu ve farkların geçirgenliğini ortadan kaldırdığı öne sürülebilir. Çünkü mekânsal farklılaşma yoluyla bir grubun üyeleri kentin belli bir yerinde yoğunlaşmakta ve bu gruplar soyo-ekonomik konumların belirleyiciliği altında olduğu kadar dini ve etnik kimlikleri, statüleri ve gelir düzeyleri ve türleri üzerinden de gettolaşmaktadır (Massey vd., 2009).

Mekânsal farklılaşma, kentteki yerleşimle ilgili bir farklılaşma olarak ortaya çıksa da farklılaşmanın nedeni toplumsal alanlardaki eşitsizliklerin örgütlenme biçimidir. Bu nedenle mekândaki farklılaşma toplumsal farklılaşmanın tezahürlerinden biridir. Bu farklılaşma biçimi mekânın politik olarak örgütlenmesinden kentleşmenin sermaye eksenli düzenlenmesindeki eşitsiz dağılıma kadar uzanan geniş bir yelpazeye sahiptir. Burada, daha önce farklı bağlamlarda tartıştı̆̆ımız bir meseleyi, bu bağlamda yeniden 
değerlendirebiliriz. ${ }^{2}$ Kentin ihtiyaç duyduğu kimlikler, mekândan, mekânsal farklılaşmasına bağımsız düşünülebilir mi? Bir başka ifadeyle, kimlikler kentteki varlıklarını kentten bağımsız ya da boşlukta mı inşa ederler?

$\mathrm{Bu}$ soru, mekânın sosyal bir ürün olmasının anlamlarından birinin mekânın mübadele değeri taşımasıyla ilgili bir sorudur. Lefebvre'nin (2000) kentleri, kullanım değerinden daha çok mübadele değeriyle değerlendirir. Bunun anlamı ekonomik alandaki gelişmeler ile kentlerin işlevi arasında zorunlu bağlar ve ilişkiler bulunduğudur. Bu nedenle bir sosyal mekân olarak kent ile bir meta olarak kent arasındaki gerilimler, mekânsal farklılaşmaya neden olur. Eğer sosyal ilişkiler, toplumdaki egemenlik ilişkilerinden bağımsız değilse, bu egemenlik ilişkilerinin türevlerinden biri olarak düzenlendiğini ifade etmek gerekir.

Lefebvre (1991) mekân, tıpkı diğer ürünler gibi ürün olduğunu ifade ettikten sonra onun bir mübadele nesnesi ve konusu olduğunu söyler. Mekânın sosyal ürün olarak kavranması, beraberinde üretim kavramını ve buna bağlı olarak gelişen sosyal ilişkileri getirir; çünkü üretim ilişkileri toplumun en küçük birimi olan aileden, en büyük birimi olan devlete kadar uzanan ve toplumsal alanlarda gerçekleşen ilişkileri belirleyenlerinden biridir; bu nedenle sosyal ilişkilerin içerisinde yer almaktadır. Sonuç olarak ekonomik ve toplumsal alanlardaki düzenlemeler mekândan bağımsız olmadıkları gibi mekânsal düzenlemelerle gerçekleşir. Ekonomik alandaki düzenlemeler, işgücünün piyasaya giriş süreçlerini değiştirmekle kalmaz, yeni sosyal ilişkiler üretir. Kent, bu değişimden doğrudan etkilenir ve mekânın yeniden düzenlenmesini sağlar ve böylelikle kenti, yeni düzenlemenin amaçlarına göre yeniden organize eder. Bu düzenleme kimliklerden inançlara, bedenden dile, ahlaktan estetiğe kadar toplumsal alanların tümünü kapsar.

Kimlik ve mekânsal farklılaşma sarmal bir ilişkiyle kurulur. Ezilen kimlikler ya da göçmenler, etnik, cinsel, dinsel azınlıklar, yoksullar, damgalananlar, kentin içinde tecrit edilenler ile kentin dışına sürülenler ve kentsel dönüşüm yoluyla mülksüzleştirilenler üzerindeki tahakküm, kimlikler yo-

\footnotetext{
2 Söz edilen çalışmada kimlik kavramına içkin olduğu öne sürülen tarihsel ve kültürel özün, kimliğin kentsel görünümde herhangi bir açıklayıcı etkisi bulunmadığı varsayımından hareketle, kimliğin inşasında rol oynayan süreçlerin izini sürmeye; sınıfsal sömürü ilişkileri ve tahakküm mekanizmaları yoluyla mekânda sınıfsal nitelik kazanan kimliğin nasıl enformelleştiğini anlamaya ve tartışmaya çalışmıştık. Ayrıntılı bilgi için bkz. Alpman, Polat S. (2015) "Kentin Tereddüdü, Kürt'ün Cazibesi: Sınıf Konusunda Susanlar, Kimlik Hakkında Konuşabilir mi?" Modus Operandi, 3, 45-74.
} 
luyla meşrulaştırılır. Bu kesimler, kimliklerine gömülmeleri, atfedilen kimliklerinden dışarı çıkmamaları istenen kesimlerdir. Bu kesimlerin bir kısmı egemenlerle ittifak içerisinde olabildiği gibi onlarla ihtilaf halinde de olabilir. Bu geniş kesimler kendi içerisinde çatışma içerisindedir ve çatışmanın taşıyıcısı kimliklerdir. Kimlikler arasında gerçekleşen çatışmalar egemen birikim rejimi için herhangi bir tehdit içermediği sürece yeniden üretilir ve sermaye-emek arasındaki çatışmanın üzerini örmeyi sağlar (Harvey, 2002).

Kimlik ve mekânsal farklılaşmanın iç içe girmesinin sonuçlarından biri işgücü piyasasının etnik, cinsel, dinsel, ırksal ve benzeri kimliklerle yeniden düzenlenmesidir. $\mathrm{Bu}$ düzenlemelerin neden olduğu eşitsizliklerin etkisini yoğun olarak tecrübe eden kesimlerden biri de göçmenlerdir. Göçmenler düşük ücretlerle ve güvencesiz olarak istihdam edilmekle birlikte göçmenlikten kurtulmalarının önüne geçen mekanizmalarla karşı karşıya bırakılırlar. Bu, göçmenleri kent içerisinde gettolara sürmek anlamına gelir ve gettolaşma işgücü piyasasında da kendini gösterir (Piore ve Safford 2007). İşücü piyasası içerisinde göçmenlere ya da egemen kimlik dışında kalanlara yönelik eşitsizlik ve ayrımclık, egemen kimliğin imtiyazlarını sürdürebilmesinin aracına dönüşürken yoksulluk sarmalı onları da içererek genişler. Egemen kimlik olan işgücü, ayrımcı tutum ve davranışlarla eşitsizliği meşrulaştıran ideolojik ve politik angajmanları, bir tür "ahlaki panik" (Wacquant, 2003: 48) içerisinde dile getirir. Ayrımcllı̆̆ın bu şekilde maskelenmesiyle eşitsizlikler süreklilik kazanır ve egemen kimlik, ekonomik ve sosyal avantajlarının önündeki olası rekabet alanlarını ayrımclıklar yoluyla ortadan düzenlemeyi hedefler. Oysa bu ayrımcılık pratikleri herhangi bir çözüm üretmediği gibi ortaya çıkan sosyal, siyasal ve ekonomik eşitsizlikler, kendini egemen kimlik içerisinde tanımlayan işgücünü de içerecek şekilde genişlemektedir. ${ }^{3}$

\footnotetext{
${ }^{3} \mathrm{Bu}$ konuyla ilgili birçok örnek verilebilir. Örneğin istihdamın güvencesiz ya da etnik işbölümüyle gerçekleştirildiği piyasada, kendini egemen kimlik olarak gören kesimlerin ücretleri süreç içerisinde düşme eğilimdedir. Ücretler düşerken ve aradaki fark kapanırken kendini egemen kimlik nedeniyle imtiyazlı sayan kesimlerin imtiyazları muhayyel hale gelmekte, söylemsel şiddet aracına dönüşmekte ve iş güvencesi sağlama imkanı ortadan kalkmaktadır. Benzer bir durum konut politikaları için de geçerlidir. Ev kiralarının yükselmesinin nedenini bu alandaki denetimsizlik ve rant geliri, konut sahipliği ve konut-kent politikalarında değil, göçmenlerin ya da mültecilerin varlı̆̆ıyla açıklayan kişiler, kısa süre içerisinde yükselen kira giderleriyle karşı karşıya kalmaktadır. Bu nedenle ücretlerin düşmesinin ya da kiraların yükselmesinin nedenlerini kimliklerle değil, sermaye - emek arasındaki ilişkilerin siyasal-iktisadi niteliğinde aramak, çözümü buradan hareketle düşünmek gerekir.
} 


\section{Farklılaşmanın Yeniden Üretimi}

Farklılaşma yalın, tekdüze ve istikrarlı değildir. Farklılaşmanın sürekliliğinin sağlanması eşitsizlik biçimlerinin, eşitsizlik üreten mekanizmaların yeniden üretilmesiyle sağlanır. Kentlerin üretim ve tüketim sürecindeki işlevi, farklılaşmanın izlerini göstermeyi kolaylaştırır. Kent sosyal yapının tümleyenlerinden biri olduğu için mekân ile sosyal yapı arasında özdeşliğe yakın bir benzerlik vardır. Başka bir ifadeyle, sosyal olan ile kentsel olan birbirinin farklı görüntüleridir ve tekil bir yapı olarak değerlendirilebilir. Sosyal yapının içerisindeki ekonomik, politik ve ideolojik ilişkiler somut/fiziksel mekân üzerinde cisimleşirken, aynı zamanda mekân bu ilişkiler yoluyla yeniden üretilir.

Castells (1977) bir eşitsizlik mekânı olarak kentleri "kolektif tüketim" (collective consumption) kavramıla açklar. Bunun başlıca nedeni, üretim ilişkilerinin kenti de aşan niteliğidir. Üretim ilişkileri kentte örgütlenir, tüketim süreçleri ise kent ile ilişkilidir. Kolektif tüketimin gerçekleştĭgi kent, aynı zamanda işgücünün yeniden üretildiği alandır. Kent, işgücü piyasası ve onun yeniden üretimi için gerekli olan ihtiyaçları sağlamakla yükümlüdür. Eğitimden sağllğa, barınmadan ulaşıma ve eğlenceye/boş zamanın organize edilmesine kadar kolektif tüketime yönelik ihtiyaçlar kentte sağlanır (Castells, 1975). Devlet kolektif tüketimin sağlayıcısı olan başlıca faildir. İşgücünün yeniden üretilmesi için gerekli olan ulaşım, barınma, sağlık gibi kolektif tüketime yönelik hizmetleri devlet sağlar ve işgücünün yeniden üretilmesi için gerekli düzenlemeler aracılığıyla mekânın yeniden organize edilmesine dahil olur.

İşgücünün yeniden üretilmesi toplumsal alanların yeniden üretilmesinin zeminini oluşturur. İşgücüyle başlayan bu süreç, Simmelci anlamda, zihniyetin yeniden üretilmesiyle çevrimini tamamlar. Bu sürecin gerçekleşmesi için tüketimin örgütlenmesi gereklidir. Kentteki mal ve hizmetler eşitsiz dağıtıldığında kentsel alan, yeni türden eşitsizliklerin ortaya çıktığı bir alana dönüşür. İleri kapitalist ülkelerdeki sınıfsal eşitsizlik tüketim üzerinden de örgütlendiği için sosyal gruplar içerisindeki eşitsizlikler, sınıfsal konumlardan tümüyle bağımsız değildir; ancak, sınıfsal konumlarla birebir uyumlu olmak zorunda da değildir. Bu nedenle ekonomik, politik, ideolojik sistem tarafından üretilen kentsel sistem, yeni sosyal eşitsizlikleri üreten bir sistemdir. Yeni eşitsizlikler, işgücü piyasasına giriş sürecinde kent ve mekânsal farklılaşma yoluyla, ötekileştirilen kimliklere yönelik bir dışlama aracına dönüşmektedir.

Devletin kolektif tüketimi düzenleyici rolündeki eşitsiz işleyişin küresel ölçekte gerçekleşmesi, küreselleşen tüketim ağlarının varlı̆̆ı, hatta küresel 
kentler olarak tanımlanan kentlerin ortaya çıkmış olması bu ilişkiyi değiştirmediği gibi küreselleşmenin sonucu olarak çıkan gelişmeler kentlerdeki toplumsal eşitsizlik ve ayrımcılığın derinleşmesine (Geniş, 2007) ve mekânsal farklılık yoluyla yeni ayrımcılıkların ortaya çıkmasına neden olur. Kimlikler, sadece sınıfsal eşitsizlik nedeniyle değil, mekânın bir tüketim ürünü olmasından kaynaklanan düzenlemeler nedeniyle de bu ayrımcilığın bir gösterenine dönüşür. Böylece mekânsal farklılaşma, yeni sosyal hareketler adı verilen politik itirazların örgütlenmesini sağlar. Eğitim, sağlık, güvenlik gibi kolektif tüketimin mekânsal olarak eşitsiz dağılımından ortaya çıkan ayrımcılıklar, kentleri itiraz mekânlarına dönüştürmektedir. “Üretim araçlarının toplumsallaşması tüketim araçlarının artan toplumsallaşmasıyla birleşince, diğer bir deyişle, ortak hizmetler günlük yaşamın yapısında ve ritminde stratejik bir rol oynamaya başlayınca, 'kentsel sorunlar' giderek siyasi bir mesele haline" (Castells, 1997) gelir. Nihayetinde kamusal hizmetler siyasal bir konudur ve kentteki siyasal mücadele, mekânsal farklılaşma nedeniyle ortaya çıan kolektif tüketimdeki farklılaşmaların bir sonucudur (Gottdiener, 1985). Mekânsal farklılaşma işgücünün yeniden üretimini sağlayan niteliği nedeniyle ekonomik düzenlemelerin bir gereği olarak sunulurken; kamusal imkanlardan ve haklardan faydalanmak söz konusu olduğunda siyasal taleplerin dile getirildiği yere dönüşür. Devletin düzenleyici işlevinin ortadan kalkması ya da eşitsizliğin devlet eliyle yeniden üretilmesi, toplumda yer alan her kesimi; yurttaşları, göçmenleri, azınlıkları ve benzeri toplulukları, yeni toplumsal hareketlerin ve mücadelelerin öznesi haline getirir (Urry, 1999).

Bu eşitsizliklerin sürdürülebilmesinin yollarından biri siyasal alanın küresel ölçekte gittikçe otoriterleşmesi ve daralması, işgücü piyasasının enformelleşmesinin norm haline gelmesi, prekarizasyonun egemen istihdam biçimine dönüşmesi ve mekânsal örgütlenmenin çok yönlü parçalanmasıdır. Bununla birlikte, Harvey'in (1982; 1993; 2002; 2010) birçok çalışmasında ve farklı bağlamlarda ifade ettiği üzere, neoliberal ekonominin toplumsal alanları düzenleme pratiğinin mekândaki somut karşllığ toplumun üyelerinin mekânsal farklılaşma yoluyla içinde bulundukları koşullara bağımlı hale getirilmesi ve böylece eşitsizliklerin sürdürülmesidir.

\section{Farklılaşmanın Ekonomi-Politiği}

Eşitsizlik mekânlarının ortaya çıkmasına neden olan, onun mübadele değerini belirleyen her şey, üretim ilişkileri içerisinde gerçekleşir. Genel anlamıla kent ve mekân, sosyalizasyon süreçlerinin tümünü kapsayan, işgücü piyasasını, üretim ilişkilerini ve sermayenin birikim sürecini içeren yer olarak 
ele alındığında, kentleri neoliberal ekonominin gelişimi, hareketi ve üretim ilişkileri düzeyinde değerlendirilebilir. Toplum - kent ilişkisi ise üretim biçiminin sosyal organizasyonu ve birikim rejiminin ihtiyaçlarıyla ilişkilidir. Mekânsal farklılaşmanın oluşma biçimi, sermaye birikiminin stratejilerinden bağımsız değildir. Bu nedenle kent, tıpkı diğer metalar gibi bir metadır (Harvey, 2002). Örneğin küreselleşme ile ortaya çıkan uluslararası sermayenin dolaşım hızı ve etkisi, endüstriyel sermayenin akışkanlığı ve yatırım biçimi sürekli değişmekte; sermaye kademeli olarak endüstriyel üretimden çekilmekte; finans sermayesi küresel ölçekte gelişmekte ve nihayetinde hizmet sektörü işgücü piyasasındaki istihdamın yoğunlaştığı alan haline gelmektedir. Bu yeni duruma uyum sağlayabilmek için işgücünün enformel istihdamı kadar kentlerin de dönüştürülmesi gerekmektedir; mekânsal farklılaşma kentlerin yeniden üretilme biçimlerinden biri olarak oluşmaktadır (Harvey, 1982).

Kentlerin egemen birikim rejimi ekseninde düzenlenmesi mekânsal farklılaşma bağlamında göçmenlerin, dini ve etnik azınlıkların ya da dışlananların maruz kaldığı tecritle sınırlı değildir; gelir dağılımından işgücü istihdamına kadar bütün toplumsal alanlarda ortaya çıkan çelişkileri ve gerilimleri içerir. İş olanaklarının ve işgücü istihdam rejiminin değişmesi, yerleşim alanlarında yaşanan değişim ve dönüşüm, erişimden ulaşıma kadar bütün gündelik yaşam akışını belirler. Ulaşımın başlı başına bir maliyet haline gelmesi, işgücü istihdamının önündeki yapısal engellerden biri haline gelir. Düşük gelir sahiplerinin konut ihtiyaçlarını karşılamak üzere kent merkezlerinde ve çöküntü mahallelerinde (slum) yoğunlaşmaları, hem ulaşım krizini aşmaya yönelik bir girişim haline gelir, hem de 'barınma ekonomisi' olarak tanımlanan yerleşim zorunluluklarını ortaya çıkarır. Kent merkezlerindeki yetersiz konut sayısı talep artışına neden olduğu için konut ve kira fiyatları yükselir. Yaşam kalitesinin düşük olmasına rağmen konut fiyatlarının yüksek olduğu mahallerde yaşayan yoksul işgücü, yeni iş imkanlarından mahrum hale gelir, vasıfsız ve düşük ücretli işlerde çalışmak zorunda kalır. Kentlerin yeniden düzenlenmesi, sermayenin daha fazla kaynağa erişimini sağlarken, bu durum faal işgücü açısından gelir dağılımında "gerileyen yeniden dağıtıma" neden olur (Harvey, 1993; 1992; 1985).

Nüfusun gittikçe artan bir biçimde kentlerde ve kent merkezlerinde yoğunlaşması, toplumun sadece yatay olarak değil dikey olarak da bölünmesiyle bir arada gelişir. Kent içerisindeki farklı mekânlar birbirlerinden sadece mekânsal olarak değil, ekonomik, sosyal, kültürel, hukuki ve siyasal nitelikler bakımından da ayrışır. Bu nedenle mekânsal farklılaşma, konutların, yerleşim yerlerinin, işliklerin ve işgücünün ayrışmasından daha çok top- 
lumsal farklılaşmanın, kimliklerin, statülerin farklılaşması olarak değerlendirilmelidir (Harvey, 2010). Bu nedenle mekânsal farklılaşmayı, "toplumsal ilişkiler temelinde oluşan yeğleme dizgesinin edilgen ürünü olarak görmek yerine, sınıfsal ilişkilerin ve toplumsal farklılaşmaların üretildiği ve sürdürüldüğü süreçler içinde tamamlayıc bir aracı etki olarak" değerlendirmek (Harvey, 2002) ve sadece işgücünün değil, işgücü piyasasının ve istihdam olanaklarını ya da egemen kimliklerin ve toplumsal cinsiyet rejiminin de mekânsal farklılaşma yoluyla bölündügüünü ifade etmek gerekir. Bu nedenle göçmen işgücü ile lokal/yerel işgücünün, egemen kimlik ile azınlık kimliğin, egemen siyaset ile alternatif siyasetlerin de mekânsal farklılaşma yoluyla gerçekleştiği ve farklı denetim-kontrol mekanizmaları içerdikleri öne sürülebilir.

\section{Sonuç}

Bu çalışma ele alınan mekân, kimlik, sınıf kavramlarının farklılaşma olgusuyla ilişkilendirilmesi ve farklılaşmanın mekânsal niteliğinin üç düzeyde analizi, modern kapitalist toplumlarda farklılıkların neden bir arada bar1namadıklarını açıklamanın yollarından biri olarak kabul edilebilir. Farklılaşma, her zaman ayrımcllık ve ayrışma nedeni olmaz. Ancak kapitalist üretim koşulları altında gerçekleşen farklılaşmalar eşitsizlik ve ayrımcılık üreten mekanizmalarla gerçekleşmektedir ve egemen birikim stratejisinin bir parçasıdır. Bu nedenle farklılaşmalar genellikle çeşitli hiyerarşilerin gösterenlerine dönüşmekte, farklılıklar arasında hegemonik ilişkilerin oluşmasına neden olmaktadır. Bu bağlamda değerlendirildiğinde kent ve mekân kavramları, toplumsal eşitsizlik ve ayrımcılık içeren pratiklerin anlaşılması ve açıklanmasında başlıca kavramlar haline gelmektedir.

Küresel bir olgu olarak gerçekleşen ve mekânsal farklılaşmaya neden olan ekonomik, siyasal ve sosyal düzenlemeler, yine küresel ölçekte yoksulluğun nedenlerinden birine dönüşmektedir. Çeşitli kimlik mekânlarının, azınlık ve göçmen mekânlarının kentsel kompozisyonun bir parçası olarak ortaya çıması ve bu mekânlar sayesinde sergilenen ayrımcı pratiklerin oluşması modern kapitalizmin gereksinimlerinin bir parçasıdır. Getto, çöküntü alanlarl, varoş ve benzeri kavramlarla ifade edilen ve metropol kentlerinin bir özelliği haline gelen bu yerlerin, yerleşim "hiyerarşisinde en altta yer alan, adı kötüye çıkmış" (Wacquant, 2011) yerler olmasının nedeni, başta ekonomi olmak üzere, toplumsal alanlar içerisinde gerçekleşen eşitsizlik ve ayrımcılık pratiklerine maruz kalanların mekânları olmasıdır. 
Mekânsal farklılaşma, görece ayrıcalıklı kesimlerin, kendilerine benzemeyen diğer sosyal gruplardan ve kimliklerden uzaklaşmaların kolaylaştırmaktadır. Mekânsal farklılaşmanın diğer köşesine sıkıştırılanlar ise kent merkezine yerleşmiş olsalar bile yalıtılmışlıkla sarmalanmış ve işsizlik, suç, damgalanma ve benzeri ayrımclıklarla mücadele etmek, sağlıksız ve köhne yerleşimlerde barınmak zorundadır. Burada yaşayan kişiler eğitim, sağlık, güvenlik, ulaşım gibi temel kolektif tüketim haklarından görece mahrum kalmaktadır. Bu mahrumiyet hali mekânla sınırlı değildir. Mekânda düzeyinde deneyimlenen tecrit, toplumsal eşitsizlik ve ayrımcllı̆ın çok boyutlu yansıdığı yerlerden biri olduğu için dikkate değerdir.

Mekânsal farklılaşma, toplumsal alanlardaki eşitsizlik ve ayrımcılıkları "yansıtır ve somutlaştırır; bunları yaratan ve sürdüren süreçler, ... kararsızlık ve çatışma mekânları" olarak karşımıza çıar. Örneğin, beyaz yakalıların barınma ihtiyaçlarını karşılamak için banliyölerdeki mekânsal farklılaşmanın sürdürülmesi gerekir ve bunun bireycilik teşvik edilir. Medyanın, reklam endüstrisinin, yeni yaşam stillerinin ve çok çeşitli propagandaların ürettiği bu mit "toplumsal ve ekonomik değişimi kuşatan bir engel" haline gelir. Toplumsal alanların neoliberal düzenlemeler tarafından belirlendiği bir düzlemde inşa edilen zihinsel formasyonun sosyal ve kültürel ayrımları kullanarak dile getirdiği ayrımcılık, kültürcülük, ırkçılık, ayrımcılık ve sayısız ötekileştirme de buna dahil edilebilir. Farklı etnik, cinsel, dinsel, kültürel ve benzeri toplulukların, topluluk bilinci içerisinde hareket etmeleri ve kolektif çıkarlarını bu bilinçle elde etmeye çalışmaları, aslında benzer koşullar altında yaşayanların ortak çıkarlarını tahrip eder ve eşitsizlik-ayrımcılık pratiklerinin yeniden üretilmesine neden olur (Harvey, 2002). Mekânsal farklılaşma ve işgücü piyasasına giriş süreci önündeki engeller, özellikle işgücü piyasasında eşit olarak yer alma talebi söz konusu olduğunda, bütünlüklü bir yapı olarak hareket eder. Bugün küresel ölçekte "yükselen bir göçmen karşıtı dalga" nun ortaya çıkması ve işgücünün farklı kesimleri içerisinde "1rkçılığın ve etnik ayrımcılığın kabarması"nın (Harvey, 2010) nedenlerinden biri de budur.

Neoliberal dönemle birlikte enformelleşmenin normlaşması, işgücü piyasasının kimlikler ekseninde yeniden düzenlenmesi, sermayenin işgücü fazlasının olduğu yerlere kaymak istemesi gibi gelişmeler sonucunda, işgücü oranı niceliksel olarak artmış, ancak oransal olarak azalmış ve çalışma koşulları gittikçe kötüleşmiş; geçimlik ekonomiye dayalı köylülük ve onun üretim sistemi yok edilmiş; kadın işgücü oranı artmış, ancak "kadın yoksulluğu" olgusu ortaya çıkmış; iki milyardan fazla kişi gettolara, favelalara ya da gecekondulara sıkışmış; günde iki dolardan daha az ücrete çalışmayı 
göze alan geniş bir yoksul kesim oluşmuş; kadınları "ev hizmeti köleliğine ve fuhşa sürükleyen uluslararası kadın ticareti" yükselmiştir. 1990'lı yıllarda bu gelişmelere yönelik itirazlar, protestolar ve toplumsal muhalefet hareketleri yükselmeye başlamış, ancak bu hareketler, 11 Eylül 2001'den sonra yavaşlamış ve etkisini kaybetmiştir (Harvey, 2010).

Bugün yoksullar, ezilenler, göçmenler, azınlık kimlikler mekânsal farklılaşma nedeniyle damgalanmakta ya da bu riskle karşı karşıya kalmaktadır. Mekânsal damgalanma, egemen kimlik dışında kalanları marjinal hale getirmenin mekânsal boyutunu oluşturur (Wacquant 2014). Sınıfsal olarak alta itildikçe kimliklerinin baskısını daha fazla hisseden bu kesimlerin bedensel ya da dış görünümlerinin, sapkınlık olarak işaretlenen inançlarının, ahlaksızlık olarak sunulan sosyalliklerinin arkasında eşitsizlik ve ayrımclık mekanizmalarının ürettiği tahakkümler yer alır. Kentteki yoksulları kimlikleri üzerinden damgalamak, onları bu ayrımc kanaatleri içselleştirmeye zorlamak, kentin içindeki gettolara itmek/sürmek, mekânın bir ayrımcılık aracı olarak kullanılmasıdır. Kent içindeki bazı mekânların etnik damgalama mekânları olması (Goffman, 2014) ya da damganın mekânsallaşması, kimlikleri mekâna sıkıştıran başlıca nedenlerden biridir.

Mekânsal farklılaşmanın kimlikler üzerinden gerçekleşmesi gettonun s1nıfsal nitelikleriyle birebir uyum içindedir. Sınıfsal olarak yaşanan çelişkiler mekânda yeniden üretilmektedir. Mekânda barınan "içerdekiler" dışardakiler tarafından damgalanırken yaşadıkları yer, bir sosyal mahrumiyet alanına dönüşür. Dışardakilerin yaşamayı tercih etmeyeceği, barınmaya değer bulmadığı, yaşamak istediğinde yıkıp yeniden yaratacağı, topluma dahil olamayan ve toplumdan hariç tutulamayan bir yerleşim yeri olan bu mekânlar, kentin içinde bile olsa ondan yalıtılmış bir yeridir (Wacquant, 2013). Burası -egemen söylemde- kavganın, huzursuzluğun, terörizmin, hırsızlığın, uyuşturucunun, cinayetin... özetle her türden suçun ve suçluluğun gerçekleştiği yerdir (Wacquant, 2011). Bu nedenle ezilenler için başarının göstereni egemen söylemin sürekli bir korku ve pislik imgesi olarak işaret edilen bu yerden kurtulmaktır (Wacquant, 2003). 


\title{
Extended Abstract
}

\section{Space, Identity, Class: Why Cannot the Differences Coexist?}

*

\author{
Polat S. Alpman \\ Yalova University
}

The first of the three sections in this study aims to understand spatial differentiation as one of the reflections of social differentiation and to understand the relations between space, identity and class concepts of inequality and discrimination. The second part of the study discusses the phenomenon of differentiation and its relationship with the concept of inequality, and the third part focuses on the dimensions, reproduction, and function of spatial differentiation. The ultimate goal of this study is to understand and explain that spatial differentiation does not have an exclusive characteristic, it is a state of dynamics, a state of dominant production regime, and its relationships with social inequality-discrimination mechanisms.

We have come to the end of the cities, which were established on the basis of the benefits of a planning and environmental policy. One of the reasons for this is that neoliberal production policies and ideology have not yet exhausted the energy of producing inequality and discrimination within social fields and relations. Today's cities have regulations in which they produce versatile inequalities and where the dynamics of separation are organized in all social fields. For this reason, social segregation takes place through space. The reason for the spatial quality of segregation is not space itself. It is important to understand how inequality and discrimination can be established, how these relations are organized and maintained, how they are organized, and how relations transform them into a sign of differentiation in the space. Space is the place where class inequalities incarnate, as well as domination by means of inclusion and exclusion mechanisms.

We can follow the differentiation through some concepts. The concepts used in social sciences have continuity and are contextual. There is no universal law that explains all the differences, like the law of universal gravi- 
tation. However, it is possible to talk about the structures, processes, and relations that transform differences into a part of inequality and discrimination relations. What makes this possible is the global structure of the dominant social formation. For this reason, it is necessary to discuss the context of the concepts in order to understand and explain the relations between space, identity, class and differentiation and their dialectical connection.

The first of these concepts is space. The concept of space is not fixed; it is, unchanging, and dateless -in brief, metaphysics. Thus, it can be defined as a place where social relations, production relations, and ideology are reproduced. At the same time, space is a place of struggle. The dynamics that are necessary for change and transformation are created there and through there. In terms of this study, space is considered as the place where seemingly unrelated things relate to each other.

Another concept is identity. Identity is conceptualized as an experience. The analytical function of the concept of identity within the social sciences is still a matter of debate. The concept of identity is used in different, multiple and intersectional meanings. This polysemy of the concept leads to an increase in the explanatory potential of the concept but facilitates its exploitation and non-contextual use. Some social scientists regard the concept of identity as an almost constant and absolute concept for the social sciences, and they attribute a specificity and explanation power to the concept itself. However, some social scientists argue that the concept of identity is used in many ways and contexts, and therefore it does not have any explanatory power. In this study, the concept of identity is defined as an experience. Experience gains meaning in a process that transcends the individuality of the person and connects them to the experiences of the social environment in which they belong. Therefore, concepts such as class, power, family, and space can be placed instead of abstract and unclear concepts such as identity and culture because these concepts are formed and emerged within the structures, processes, and relations that take place in daily life.

Another concept that shows differentiation is class. The re-emergence of the concept of class within the social sciences is a factual result of neoliberal economic-political, informalization, and precarization. It is necessary to look for the class, not as a structure or a category, but as the answer to the question of how the person acquired her/his social role and function and how it is the relationship with the property rights and authority structure. Looking for the class in the socio-political processes and relationships 
set up in daily life suggests that the class differences built on social inequalities and discrimination are reproduced in social processes. Therefore, the class is a relationship. Defining the class as a relationship establishes the context by determining the scope and limits of this relationship.

The relationship of these concepts with spatial differentiation can be examined at three levels. The first of these levels is related to the dimensions of differentiation, the second to the reproduction of differentiation, and the third is related to the economic-political critique of differentiation.

Cities are the space where production, consumption, distribution and exchange processes and relations take place. The regulation of these processes and relations leads to the regulation of the remaining social fields. In order to sustain the accumulation of economic capital, it is necessary to ensure continuity on the global, regional and local levels. These regulations cover the rest of the society as well as the rest of the society from family to law, from education to politics. It also includes a combination of the relations of production, the production regime, the state, and daily life.

There are many forms of inequality that cause spatial differentiation to occur. The dimensions of differentiation cover all the social fields from economy to culture. Social regulations become the determinants of class, cultural, ethnic, religious, sexual identities in urban settlements, locating behaviors and settlement strategies. It causes the reproduction of differentiation in the city and the reorganization of the labor market through spatial differentiation. The founding element here is identity. Oppressed identities or immigrants, ethnic, sexual, religious minorities, the poor, the stigmatized, those who are isolated in the city and those driven out of the city and those who are dispossessed by urban transformation are legitimized through their identities. One of the consequences of the nesting of identity and spatial differentiation is the reorganization of the labor market with ethnic, sexual, religious, racial and similar identities.

In order to maintain inequality and discrimination, differentiation needs to be reproduced. The continuity of differentiation is ensured by the reproduction of the forms of inequality and the mechanisms that produce inequality. While the economic, political and ideological relations within the social structure are embodied on a concrete / physical space, space is reproduced through these relations. Thus, the concrete provision of the social regulations of the neoliberal economy in the space is to make the people dependent on the conditions under which they exist through spatial differentiation, thus reproducing inequalities. 
Everything that causes the emergence of inequality spaces, which determines the value of its exchange, takes place within the relations of production. The relationship between society and the city is related to the social organization of the mode of production and the needs of the accumulation regime. The form of spatial differentiation is not independent of the strategies of capital accumulation. For this reason, the city is just like other commodities. In order to adapt to this situation, cities should be transformed as much as the informal employment of the labor force. For this reason, spatial differentiation is formed as one of the ways in which cities are reproduced. Persons are affected by this process according to their class positions. Despite the low quality of life, the poor labor force living in places with high housing prices is deprived of new jobs and has to work low paying jobs. While reorganization of cities provides capital to access more resources, this situation causes regression in the distribution of income in terms of active labor force. The class contradictions in the space become part of the economic-political conflict in the society.

\section{Kaynakça/References}

Bauman, Z. (2013). Modernite, kapitalizm, sosyalizm: Küresel çağda sosyal eşitsizlik. (F. D. Ergun, Çev.). İstanbul: Say.

Berger, P. L. ve Luckmann, T. (1991). The social construction of reality: A treatise in the sociology of knowledge. New York: Penguin.

Blau, P. M. (1977). Inequality and heterogeneity: A primitive theory of social structure. New York: Free Press.

Brubaker, R. ve Cooper, F. (2000). Beyond identity. Theory and Society, 29, 1-47.

Burawoy, M. (1983). Between the labor process and the state. American Sociological Review, 48 (5), 587-605.

Carnoy, M. ve Castells, M. (2001). Globalization, the knowledge society, and the network state: Poulantzas at the millennium. Global Networks, 1 (1), 1-18.

Castells, M. (1975). Advanced capitalism, collective consumption and urban contradictions. L. N. Lindberg, R. Alford, C. Crouch, C. Offe (Der.), Stress and Contradictions in Modern Capitalism içinde, Massachusetts: Lexington Books.

Castells, M. (1977). The urban question: A Marxist approach. (A. Sheridan, Çev.). London: Edward Amold.

Castells, M. (1997). Kent, sınıf, iktidar. (A. Erendil, Çev.). Ankara: Bilim ve Sanat.

Cerulo, K. A. (1997). Identity construction: New 1ssues, new directions. Annual Review of Sociology, 23 (1), 385-409.

Geniş, Ş. (2007). Küreselleşme, toplumsal eşitsizlik ve mekânsal ayrışma. Sivil Toplum, (17-18), 69-84. 
Geniş, Ş. (2007). Producing elite localities: The rise of gated communities in Istanbul. Urban Studies, 44 (4), 771-798.

Goffman, E. (2014). Damga: Örselenmiş kimliğin idare edilişi üzerine notlar. (Ş. Geniş, L. Ünsaldı ve S. N. Ağırnaslı, Çev.). Ankara: Heretik.

Gottdiener, M. (1985). The social production of urban space. Austin: University of Texsas.

Göker, G. (2017). Dijital heterotopyalar: 'Başka' bir bağlamda yeni medya. Selçuk İletişim, 9 (4), 164-188.

Hall, S. (1997). The local and the global: Globalization and ethnicity. A. D. King (Der.), Culture, globalization and the world-system: Contemporary conditions for the representation of $\imath$ dentity içinde, Minneapolis: University of Minnesota Press.

Hall, S. (2003). Who needs identity. S. Hall ve P. du Gay (Der.), Questions of cultural identity içinde, London: Sage.

Harvey, D. (1982). The limits to capital, Oxford: Basil Blackwell.

Harvey, D. (1993). Social justice and the city, Oxford: Blackwell.

Harvey, D. (2002). Sınıfsal yapı ve mekânsal farklılaşma kuramı. B. Duru ve A. Alkan (Der.), 20. yüzyıl kenti içinde, Ankara: İmge.

Harvey, D. (2010). Sermaye muamması: Kapitalizmin krizleri. (S. Savran, Çev.). İstanbul: Sel.

Hirsch, J. (2011). Materyalist devlet teorisi: Kapitalist devletler sisteminin dönüşüm süreçleri. (L. Bakaç, Çev.). İstanbul: Alan.

Jenkins, R. (2004). Social identity, New York: Routledge.

Jessop, B. ve Sum, N. L. (2006). Beyond the regulation approach: Putting capitalist economies in their place. Cheltenham: Edward Elgar.

Laclau, E. ve Mouffe, C. (2008). Hegemonya ve sosyalist strateji. (A. Kardam, Çev.). İstanbul: İletişim.

Lefebvre, H. (1991). The production of space. (D. N. Smith, Çev.). Oxford: Blackwell.

Lefebvre, H. (2000). Right to the city. E. Kofman, E. Lebas (Der.), Writings on cities içinde, Oxford: Blackwell.

Lipietz, A. (1988). Accumulation, crises and the ways out: Some methodological reflections on the concept of regulation. International Journal of Political Economy, 18 (2), 10-43.

Marcuse, P. (2009). From critical urban theory to the right to the city. City, 13 (2), 185-197.

Marx, K. (2011). Kapital, Cilt:1. (M. Selik ve N. Satligan, Çev.). İstanbul: Yordam.

Massey, D. S.; Rothwell, J. ve Domina, T. (2009). The changing bases of segregation in the united states. The Annals of the American Academy of Polical and Social Science, 626, 74-90.

Nielsen, K. (1991). Towards a flexible future: Theories and politics. B. Jessop, H. Kastendiek, K. Nielsen, O. Pedersen (Der.), The politics of flexibility: Restructuring, state and industry in Britain, Germany and scandinavia içinde, London: Edward Elgar. 
Pierson, C. (2004). Continuity and discontinuity in the emergence of the 'PostFordist' Welfare State. R. Burrows ve B. Loader (Der.), Towards a Post-Fordist welfare state içinde, New York: Taylor \& Francis.

Piore, M. J. ve Safford, S. (2007). Preliminary thoughts on identity and segmentation in primary sector labor markets. Socio-Economie Du Travail, 41 (6), 925940.

Santas, A. (2002). Some consequences of mead's institutional theory of the Self. P. C. Bube, J. L. Geller (Der.), Conversations with pragmatism: A multidisciplinary study içinde, New York: Rodopi.

Soja, E. (2009). The city and spatial justice. Justice Spatiale, 1, 1-5. 20 Ocak 2019 tarihinde https://goo.gl/zwLRnr adresinden erişildi.

Sökefeld, M. (2001). Reconsidering identity. Anthropos, 96 (2), 527-544.

Standing, G. (1999). Global labour flexibility: Seeking, distributive, justice, London: MacMillan.

Standing, G. (2011). The precariat: The new dangerous class. New York: Bloomsbury.

Taylor, G. ve Spencer, S. (2004). Social identities: Multidisciplinary approaches, New York: Routledge.

Theodore, N.; Peck, J. ve Brenner, N. (2012). Neoliberal kentçilik: Kentler ve piyasaların egemenliği. (Ş. Geniş, Çev.). İdeal Kent, 7, 21-37.

Thompson, E. P. (2004). İngiliz işçi sınıfının oluşumu. (U. Kocabaşoğlu, Çev.). İstanbul: Birikim.

Thompson, E. P. (2006). Avam ve görenek. (U. Kocabaşoğlu, Çev.). İstanbul: Birikim. Turner, B. (1997). Eşitlik. (B. S. Şener, Çev.). Ankara: Dost.

Wacquant, L. (2003). Fransız banliyöleri ve amerikan zenci gettosu: Karıştırma yerine karşılaştırma. Toplum Bilim, 17, 45-55.

Wacquant, L. (2013). İleri marjinallik çağında bölgesel damgalama. Ö. Aytaç ve S. İlhan (Der.), Kentsel yoksulluğu yeniden düşünmek içinde, Ankara: Birleşik.

Wacquant, L. (2014). Neoliberal şehirde marjinallik, etnisite ve cezalandırma: Analitik bir kartografya. S. Torlak ve Ö. Kulak (Der.), Mekân Meselesi içinde, Ankara: Tekin.

Wacquant, L. (2011). Kent paryaları: İleri marjinalliğin karşılaştırmalı sosyolojisi. (M. Doğan, Çev.). İstanbul: Boğaziçi Üniversitesi Yayınları.

Wood, E.M. (2006). Sınıftan kaçış: Yeni 'hakiki' sosyalizm. (Ş. Alpagut, Çev.). İstanbul: Yordam.

Yarcı, S. (2017). Toplumsal bir iletişim şekli olarak yeni toplumsal hareketler: Gezi Parkı örnekleminin Luhmanncı analizi, (Yayımlanmamış Doktora Tezi), Sakarya Üniversitesi, Sakarya.

Polat S. Alpman İlk, orta, lise eğitimimi İstanbul'da tamamladı. 2005 yılında Sosyoloji lisans, 2007 yılında Eğitim Bilimleri, 2009 yılında ise Sosyoloji bölümünden Yüksek Lisans derecesi alan Alpman, 2015 yılında Ankara Üniversitesi, Sosyal Bilimler Enstitüsü'nde Sosyoloji doktorasını tamamladı. Akademik ilgi alanı göç, kent, devlet, sınıf, kimlik ve ideoloji olan Alpman'ın başta Politik SosyalBilim, Top- 
lum ve Bilim, Praksis ve Birikim dergileri olmak üzere yayınlanmış makaleleri, çeşitli konularda yayınlanmış kitap bölümleri ve İletişim Yayınları tarafından yayımlanan Esmer Yakalılar: Kent, Sınıf, Kimlik ve Kürt Emeği isimli bir kitabı bulunmaktadır. Yalova Üniversitesi'nde öğretim üyesi olarak çalışmaktadır.

Polat S. Alpman is graduated from the Department of Sociology of Selcuk University in 2005. He completed his MSc on Educational Sciences and Sociology. He accomplished PhD degrees on Sociology from Ankara University, the Department of Sociology. He is currently an academic staff member of Yalova University, Social Services, and Consultancy Department.

E-mail: polat_alpman@yahoo.com 